\title{
Seed nutripriming with zinc is an apt tool to alleviate malnutrition
}

\author{
Mathew Veena $\cdot$ Jos T. Puthur $\mathbb{D}$
}

Received: 28 March 2021 / Accepted: 26 July 2021 / Published online: 7 August 2021

(C) The Author(s), under exclusive licence to Springer Nature B.V. 2021

\begin{abstract}
More than 2 billion people worldwide suffer from micronutrient malnutrition, sometimes known as hidden hunger. Zn malnutrition affects around a third of the world's population. The physicochemical features of soil, which limit the availability of $\mathrm{Zn}$ to plants, cause $\mathrm{Zn}$ deficiency. The eating habits of certain populations are more depended on $\mathrm{Zn}$ deficient staple foods. Due to the high expense and certain interventions such as diet diversification, zinc supplementation and food fortification cannot be achieved in disadvantaged populations. Biofortification is the most practical technique for alleviating $\mathrm{Zn}$ malnutrition. Seed priming with nutrients is a promising biofortification approach for edible crops. Seed nutripriming with zinc is a cost-effective and environmentally benign approach of biofortification. Seeds can be nutriprimed with $\mathrm{Zn}$ using a variety of methods such as Zn fertilisers, Zn chelated compounds and $\mathrm{Zn}$ nanoparticles. Nutripriming with nanoparticles is gaining popularity these days due to its numerous advantages and vast biofortification potential. Seeds enriched with $\mathrm{Zn}$ also aid plant performance in $\mathrm{Zn}$ deficient soil. $\mathrm{Zn}$ an essential trace element can regulate physiological, biochemical and molecular processes of plant cells and thus can enhance
\end{abstract}

M. Veena · J. T. Puthur $(\bowtie)$

Plant Physiology and Biochemistry Division, Department of Botany, University of Calicut, C. U. Campus P.O,

Calicut, Kerala 673635, India

e-mail: jtputhur@yahoo.com germination, growth, yield and bioavailable $\mathrm{Zn}$ in edible crops. Moreover, zinc emerges as an important element of choice for the management of COVID-19 symptoms.

Keywords Biofortification - Chelators · Fertilisers · Micronutrient · Nanoparticles · Seed germination · Photosynthesis

\section{Introduction}

Mineral nutrients are inevitable for the normal growth, development and reproduction of plants and animals including humans. At least 14 mineral elements are indispensable for plants (White \& Brown, 2010) while humans require 23 mineral elements (Huang et al., 2020; White \& Brown, 2010). Zinc (Zn) a chalcophile with atomic number 30 is a transition metal and ranks 23rd in abundance on earth (Broadley et al., 2007). It is an essential micronutrient required in trace and plays catalytic, structural, regulatory and signalling roles in all organisms (Gibson, 2012). It is the sole metal present in all six enzyme classes including oxidoreductases, transferases, hydrolases, lyases, isomerases and ligases (Barak \& Helmke, 1993; Majumder et al., 2019). It is also present in transcription factors such as zinc finger family of transcription factors, thus having a role in gene expression (Andresen et al., 2018; 
Heidari-Beni et al., 2021). It is essential for DNA replication and transcription as RNA polymerase and DNA polymerase need $\mathrm{Zn}$ for their activity (Chanfreau, 2013; Wu \& Wu, 1987). In physiological conditions, it is a non-redox active element due to a complete $\mathrm{d}$ shell of electrons (Yruela, 2013), making it suitable to perform diverse biological roles (Ishimaru et al., 2011).

Green revolution has increased the yield of staple food crops so as to feed the growing population. But the unanticipated outcome of this achievement was micronutrient malnutrition (Graham et al., 2012). Worldwide, above 2 billion people suffer from micronutrient malnutrition or hidden hunger and it have negative impact on the socioeconomic status of a country (Bailey et al., 2015). Among micronutrient malnutrition, $\mathrm{Zn}$ malnutrition is a major threat affecting both plants and human health. Globally, over $30 \%$ of the people is suffering from $\mathrm{Zn}$ deficiency, majority in developing countries due to dependence on monotonous staple food such as cereals, which are inherently low in bioavailable Zn (Impa et al., 2012; Cakmak \& Kutman, 2018).

The present state of coronavirus disease 2019 (COVID-19) pandemic, an acute respiratory disease, is currently devasting the socioeconomic condition of the world. The risk factors include poor nutrition, preexisting non-communicable diseases with a compromised immune system, which becomes prone to severe infection and eventually leads to death due to pneumonia. Zn supplements are administrated along with other therapeutic agents in COVID-19 treatment (Derwanda and Scholz, 2020; Khayyatzadeh, 2020; Muscogiuri et al., 2020; Rahman \& Idid, 2020; Skalny et al., 2020) as it is effective in antiviral immunity (Read et al., 2019). To ward off the virus, $\mathrm{Zn}^{2+}$ ions can inhibit RNA-dependent RNA polymerase, which is needed for the replication of these viruses (te Velthuis et al., 2010) and $\mathrm{Zn}$ finger antiviral proteins will efficiently bind and degrade the viral RNA that invade a host cell (Luo et al., 2020; Meagher et al., 2019).

To alleviate $\mathrm{Zn}$ malnutrition, various approaches like diet diversification, $\mathrm{Zn}$ supplementation, food fortification and biofortification are implemented. However, the most feasible, sustainable and costeffective approach is biofortification, so that it reaches to the marginalised population. Biofortification is the method of enriching edible portions of food crops with bioavailable vitamins and micronutrients. It comprises of three strategies, agronomic biofortification, plant breeding approach and transgenic biofortification (Garg et al., 2018).

Agronomic biofortification is the application of $\mathrm{Zn}$ containing compounds (as fertilisers, chelated compounds, nanoparticles) to soil, plant or seed and is a rapid and effective method of biofortification (Valença et al., 2017). In plant breeding, nutrient-rich parent lines are identified and crossed with modern high yielding but nutritionally poor varieties, to produce high yielding and nutritionally enriched varieties (Saltzman et al., 2017). Various recombinant technologies like gene silencing, overexpressing or gene insertion from another taxon can be employed to biofortify edible crops with essential nutrients (White \& Broadley, 2011).

Seed priming is a practical, profitable, simple, powerful method, comprising of hydrating seeds in a controlled way to initiate many metabolic pathways, and further these hydrated seeds are dried back to their original weight before sowing (Farooq et al., 2006; Jisha et al., 2013). An agronomic approach to tackle the nutrient deficiency of plants as well as in humans is to treat the seeds with the deficient nutrient. Thus, seeds can be treated with macro- and micronutrients in order to reduce the nutrient deficiencies (Atar et al., 2020). In addition to this, seed priming with micronutrient improves the nutritional components, such as protein content (Rehman et al., 2015; Seddigh et al., 2016), and reduces antinutritional factors like $\mathrm{Cd}$ and phytate (Slamet-Loedin et al., 2015). The present review focuses on seed priming with $\mathrm{Zn}$ compounds ( $\mathrm{Zn}$ nutripriming) as an effective methodology for biofortification of staple food crops.

\section{Zinc in soil and factors affecting phytoavailability of $\mathbf{Z n}$}

The $\mathrm{Zn}$ present in the soil comes through natural and anthropogenic activities. The weathering of rock is the principal natural source, while industrial and agricultural activities such as smelters and Zn-rich fertilisers are the anthropogenic sources. The nature of parent rock, soil type, soil order, $\mathrm{pH}$, climatic factors, moisture content, microbial and human activities contribute generously to zinc present in the soil (Tsonev and Lidon, 2012). In soil, Zn occurs in five 
different forms, water-soluble form, exchangeable form, non-exchangeable form, adsorbed or chelated organic form, chelated to primary weathering minerals. The absorption-desorption processes between the soluble and adsorbed forms contribute to the available $\mathrm{Zn}$ in soil. The total $\mathrm{Zn}$ in regular soil is within the range of 10-300 ppm. The average amount of $\mathrm{Zn}$ in the soil is about $50 \mathrm{ppm}$. The total $\mathrm{Zn}$ present in the soil is not readily available for plants. Only a tiny proportion of the soil $\mathrm{Zn}$ is phytoavailable. This phytoavailable Zn can be determined by extracting Zn with DTPA (diethylenetriaminepentaacetic acid). Thus, in a given soil the DTPA-extractable $\mathrm{Zn}$ corresponds to phytoavailable $\mathrm{Zn}$ present in that soil (Sharma et al., 2013). Zn deficiency is indicated as a soil having less than 0.8 ppm DTPA-extractable Zn (Wissuwa et al., 2008).

Various factors affect the phytoavailability of $\mathrm{Zn}$ in soil. These factors include the $\mathrm{pH}$, redox reactions, organic matter content, clay content, humus content, cation exchange capacity, microbial activity, soil structure, water content and interactions with other elements. These factors either alone or in various combinations impede the availability of $\mathrm{Zn}$ to the plants. The $\mathrm{pH}$ of the given soil contributes well to the solubility of $\mathrm{Zn}$. In acidic $\mathrm{pH}$ below 7.7 , the $\mathrm{Zn}$ is present in the soil as divalent cation $\mathrm{Zn}^{2+}$, a readily available form for plants. In basic $\mathrm{pH}$, between 7.7 and 9, $\mathrm{Zn}$ is seen as monovalent cation $\mathrm{ZnOH}^{+}$, and to some extent plants can absorb this form; above 9, it is seen as $\mathrm{Zn}(\mathrm{OH})_{2}$. In alkaline soil, the phytoavailability of $\mathrm{Zn}$ in soil decreases sharply; usually, the $\mathrm{Zn}$ present will be sorbed and may not be readily available. When $\mathrm{CaCO}_{3}$ is present in the soil, the $\mathrm{Zn}$ present in the soil gets adsorbed to it in a nonexchangeable form, and the formation of insoluble calcium zincate also occurs. Moreover, the soil $\mathrm{pH}$ increases; thus, overall, the calcareousness decreases the availability of $\mathrm{Zn}$ in this soil (Prasad et al., 2014).

In a general view, the presence of organic matter in soil increases the phytoavailability of $\mathrm{Zn}$. Organic matter in soil can either solubilise the $\mathrm{Zn}$ or fix the $\mathrm{Zn}$ in soil. The solubilised form of $\mathrm{Zn}$ is readily available to plants, while the fixed one is not available for plants (Dhaliwal et al., 2019). The principal component analysis done by Baran et al. (2018) revealed that organic carbon is an essential factor that determines the phytoavailability of $\mathrm{Zn}$ in soil. According to the differential solubility, organic matter in soil is divided into fulvic acid, humic acid and humin. Usually, the $\mathrm{Zn}$ bound to them is in a locked form and is least available for plants. However, the $\mathrm{Zn}$ present in the fulvic acids is more mobile and available for plants due to its high mobility and hydrophilicity (Benedet et al., 2020). Organic matter can also influence the cation exchange capacity (CEC) of the soil. CEC is the potential of the soil to hold and exchange positively charged ions. When the CEC of soil is high, the exchangeable form of $\mathrm{Zn}$ present in the soil can be available for plants. Karimi et al. (2019) could increase the availability of $\mathrm{Zn}$ in calcareous saline soil by increasing the organic matter and cation exchange capacity of soil by the application of biochar.

The soil microorganisms such as zinc solubilising and mobilising bacteria and many arbuscular mycorrhizae can solubilise the $\mathrm{Zn}$ in the rhizosphere by acidifying the region by secreting phytosiderophores or by secreting phenolics. Thus, if the factors affecting their growth are suitable, they can increase the phytoavailability of Zn (Singh \& Prasanna, 2020). The application of zinc solubilising Enterobacter sp. MN17, along with other $\mathrm{Zn}$ application methods, increased chickpea's yield and quality (Ullah et al., 2020). The soil structure and its water retention capacity have an essential role in maintaining phytoavailable $\mathrm{Zn}$ in the soil. The porous and well-aerated soil with good moisture content can make $\mathrm{Zn}$ available to a certain extent. The presence of clay also reduces the availability of $\mathrm{Zn}$. At the same time, flooding may create an anaerobic condition in the soil and interfere with $\mathrm{Zn}$ 's availability. Even though it increases the $\mathrm{Zn}$ content initially, later insoluble $\mathrm{Zn}$ contents are formed (Rehman et al., 2018). An analysis from 153 drylands indicated a decrease in total and soluble $\mathrm{Zn}$ (Moreno-Jiménez et al., 2019).

Phosphorous in the soil can interfere with the availability of $\mathrm{Zn}$ to the plants from the soil. In both acidic and alkaline soil, the addition of phosphorous decreased the DTPA-extractable $\mathrm{Zn}$, and the root and the shoot $\mathrm{Zn}$ content were also decreased in the wheat plant. This decrease of $\mathrm{Zn}$ in tissue concentration was more in alkaline soil than the acidic soil (Chen et al., 2019). Upon application of phosphorous, the concentration of $\mathrm{Zn}$ in various staple crops such as wheat and maize decreased to the extent of $16.6 \%$ and $20.2 \%$, respectively. This reduction in $\mathrm{Zn}$ content is corroborated with the reduction in arbuscular mycorrhizal 
colonisation of roots (Zhang et al., 2021). Nitrogen positively influences the soil $\mathrm{Zn}$ availability as well as the grain $\mathrm{Zn}$ content. A field study conducted by Jaksomak et al. (2017) in 5 rice varieties indicated an increase in grain $\mathrm{Zn}$ and yield in low-grain/high-yield varieties while increased the yield and decreased the $\mathrm{Zn}$ in high $\mathrm{Zn} /$ low yield varieties.

\section{Zinc from soil to plants}

The mobility of $\mathrm{Zn}$ from the rhizosphere to the root system of a plant is determined by the plant type, root characteristics, physicochemical properties of soil and various plant-microbe interactions. The roots absorb $\mathrm{Zn}$ as a divalent $\mathrm{Zn}$ ion form. Like all the nutrients, the need for $\mathrm{Zn}$ by plants during various phases of the life cycle is different. Thus, according to the genetic makeup and physiological need for $\mathrm{Zn}$, plants can increase the solubility and absorption of $\mathrm{Zn}$ from the soil by acidifying the rhizosphere. In plants, the root can exudate proton, organic acids like citric acid, malic acid and oxalic acid. Plants can actively absorb the $\mathrm{Zn}$ by hyperpolarising the root cell plasma membrane with the aid of ATPase. In cereal crops, there is an additional mechanism and it is by releasing phytosiderophores into the soil, which forms complexes with $\mathrm{Zn}$, aiding in the absorption of $\mathrm{Zn}$ (Gupta et al., 2016). Arbuscular mycorrhizae (AM) can alter the physicochemical properties of soil, and through phosphatase, dehydrogenase activities and releasing glomalin glycoprotein, they facilitate the uptake of $\mathrm{Zn}$ from the soil. A field study in maize for increasing grain $\mathrm{Zn}$ content by the activity of zinc solubilising bacteria and AM mycorrhizae has found promising results (Suganya et al., 2020).

Within the plant, transporter proteins are necessary for translocation and storage of $\mathrm{Zn}$ in edible portions. These proteins play an essential role in the translocation of metal ions into and out of the cell, microcompartments, and sequestering these ions in vacuoles to act as a reservoir or reduce toxicity. Mainly three transporter systems are elucidated for $\mathrm{Zn}$ transport. They are the ZIP (zinc-iron permease or ZRT, IRTlike proteins) family of transporters seen on the plasma membrane. The CDFs (cation diffusion facilitator) like MTPs (metal tolerance protein), seen on tonoplasts and HMAs (Heavy Metal ATPase) a P-type ATPase, localised on the plasma membrane, tonoplast and endomembrane system (Caroli et al., 2020). Usually, $\mathrm{Zn}$ is transported within the plant as $\mathrm{Zn}{ }^{2+}$ or complexed with protein, amino acids and organic acids. In the xylem, translocation of $\mathrm{Zn}$ occurs mainly as $\mathrm{Zn}^{2+}$ or complexed with histidine or nicotianamine (NA) while in the phloem, $\mathrm{Zn}$ is mostly as complexed with small proteins and NA. Zn can reach the storage tissues via xylem or phloem (White \& Broadley, 2009).

Plants require optimum concentration of $\mathrm{Zn}$ for the growth and functioning of specific metabolic processes. The concentration of $\mathrm{Zn}$ in many plants ranges between 30 and $100 \mathrm{mg} \mathrm{Zn/Kg}$ dry weight and above this is toxic, even though some hyperaccumulators possess above this range (Noulas et al., 2018). The concentration of $\mathrm{Zn}$ below 15-20 $\mu \mathrm{g}$ per gram dried leaves shows $\mathrm{Zn}$ deficiency (Heidari-Beni et al., 2015; Mitra, 2015). It is important in chlorophyll biosynthesis, IAA metabolism, pollen formation, maintenance of membrane integrity, protection against photooxidative damage (Noulas et al., 2018) and takes part in the repair of PSII, by replenishing the photodamaged D1 protein (Li et al., 2020; Woodson, 2019).

Zinc deficiency in plants occurs due to the lack of phytoavailable $\mathrm{Zn}$ in the soil. The phytoavailability of $\mathrm{Zn}$ in the soil decreases with high $\mathrm{pH}$, calcareousness, very high and low organic content, clay, high phosphorous content (Alloway, 2009; Hafeez et al., 2013; Pourmirzaiee et al., 2018). Growing crop plants in such soils decrease its growth, yield and quality. The deficiency of $\mathrm{Zn}$ in plants causes stunted growth, chlorosis, smaller leaves, sterile spikelets (Das et al., 2018), decrease in fruit size, inhibition in shoot elongation, reduced $\mathrm{Cu} / \mathrm{Zn}$ superoxide dismutase (SOD) activity, enhanced photooxidation, oxidative damage of membranes, proteins, phospholipids, chlorophyll molecules, nucleic acids, SH group containing enzymes, IAA inhibition (Zaman et al., 2018), synthesis of impaired protein, increase in ROS, decrease in detoxification mechanism (Cakmak, 2000). A decrease in chlorophyll content, lower chl $a: b$ ratio, reduction in PS II per leaf area, impaired quantum efficiency of PS II, in effect a decline in photosynthetic performance occurs in $\mathrm{Zn}$-deficient plants (Chen et al., 2007). 
$\mathrm{Zn}$ in edible portions of crops

The plants growing in similar conditions differ significantly in absorption, translocation, accumulation and storage of $\mathrm{Zn}$. The rich sources of $\mathrm{Zn}$ within the plants include leafy vegetables, and the least available source includes cereals. It may be due to the immobile nature of $\mathrm{Zn}$ within the plant tissue, primarily through the phloem. Usually, the seeds, fruits, tubers are phloem fed tissues; thus, the amount of $\mathrm{Zn}$ in these edible portions will be low. When compared to the cereals, the legumes contain more $\mathrm{Zn}$. Amaranthaceae, Brassicaceae and Salicaceae accumulate more $\mathrm{Zn}$ content, whereas the Poaceae, Solanaceae and Linaceae acquire least $\mathrm{Zn}$ content (Akhtar et al., 2019; Gregory et al., 2017). Even though fruits are poor sources of $\mathrm{Zn}$, pomegranate is rich in $\mathrm{Zn}$. It contains $\mathrm{Zn}$ to the level of 9.97-17.29 $\mathrm{mg} \mathrm{kg}^{-1}$ fresh weight (Tozzi et al., 2020). A study conducted in 8 citrus fruit cultivars found that the $\mathrm{Zn}$ concentration within them is in the range of $0.10-0.24 \mathrm{mg} / 100 \mathrm{~g}$ fresh weight (Czech et al., 2020). The $\mathrm{Zn}$ in edible portions of plants is dependent on the genetic makeup and environment of the plant.

\section{Zinc in human}

The recommended daily intake of $\mathrm{Zn}$, depending on age, gender, diet is between 3 and $16 \mathrm{mg} \mathrm{Zn}$ per day. No long-term storage system is present for $\mathrm{Zn}$ in humans, so daily dietary intake is necessary to maintain $\mathrm{Zn}$ in acceptable range (Hotz \& Brown, 2004). $\mathrm{Zn}$ is obtained by humans via a wide range of foods. Animal-based foods are more nutritious and bioavailable than plant-based foods. $\mathrm{Zn}$ is found in abundance in oysters. Beef, hog, lamb, chicken and their products are high in $\mathrm{Zn}$ content than other meats. Milk and milk products can also provide $\mathrm{Zn}$ to humans. $\mathrm{Zn}$ is also found in leafy vegetables, beans, tubers and cereals. Plant products, on the other hand, are less bioavailable due to the presence of antinutrients such as phytate (McClung, 2019; Chasapis et al., 2020). The physiological requirement of $\mathrm{Zn}$ is high during pregnancy, infancy, lactation and adolescence. Zn plays important role in immune system, sensory system, reproduction, oxidative stress, apoptosis, neurobehavioural development and also acts as a neurotransmitter (Gammoh \& Rink, 2019; Prasad, 2008; Wani et al., 2017).

In infants and children, $\mathrm{Zn}$ deficiency results in compromised neuro-behavioural function. Acrodermatitis enteropathica is a genetic disorder that is contributed by poor $\mathrm{Zn}$ absorption in humans (Ogawa et al., 2018). In humans, $\mathrm{Zn}$ deficiency leads to learning disability, decrease in physical growth, delay in sexual maturity, vulnerability to diarrhoea and pneumonia, malfunctioned immune system and increase in infections and mortality. Among elderly, Zn deficiency results in chronic non-healing ulcers, impaired taste sensitivity and compromised immune system (Chasapis et al., 2020).

\section{Causes of $\mathrm{Zn}$ malnutrition}

Zinc deficiency ranks fifth in developing countries and eleventh in world as risk factor responsible for morbidity and mortality in humans (WHO, 2002). The most important reason behind $\mathrm{Zn}$ deficiency is intake of $\mathrm{Zn}$-deficient diet or consumption of food with low bioavailable $\mathrm{Zn}$, such as food with high phytate content (Clemens, 2014). Zn deficiency is also caused by increased demands, malabsorption, impaired usage and increased losses. Malnutrition could be caused by any of these conditions, alone or in combination. These issues might also occur as a result of physiological or pathological situations that necessitate higher $\mathrm{Zn}$ levels. The bioavailability of $\mathrm{Zn}$ might potentially be hampered by the use of certain medications (Hotz \& Brown, 2004).

Some people are hesitant to ingest animal-based foods because of religious beliefs. Vegans and vegetarians face the same difficulties. Zn availability in a plant-based diet is influenced by soil $\mathrm{Zn}$ levels as well as antinutrients such as phytate, calcium and polyphenols (Gupta et al., 2020). The majority of people in developing and impoverished nations rely on one or more cereal crops as a main meal. The majority of people in these countries rely on their agricultural fields for food and survival. Their dietary variety is relatively limited. They are not able to afford the variety of food items such as animal-based food which are rich in $\mathrm{Zn}$. Moreover, the $\mathrm{Zn}$ condition of the soil plays a critical role in Zn deficiency. Typically, soil Zn deficiency corresponds to $\mathrm{Zn}$ malnutrition in certain parts of the world. Zn deficiency affects almost half of all cereal cultivation regions, and growing these cereal 
varieties in Zn-poor soil reduces the amount of bioavailable $\mathrm{Zn}$ in these genetically deficient $\mathrm{Zn}$ crops. After milling and polishing, cereal grains such as rice and wheat are commonly consumed. As $\mathrm{Zn}$ concentration is higher in the hull, bran and embryo of grains than in the endosperm, the bioavailability of $\mathrm{Zn}$ from such crops is reduced further (Cakmak \& Kutman, 2018).

Rice-wheat cropping is one of the most important agricultural systems in South Asia. Some of the causes behind $\mathrm{Zn}$ deficiency in these regions include extensive cropping, injudicious use of fertilisers such as $\mathrm{N}$, $\mathrm{P}$ and $\mathrm{K}$, and poor management of on-farm residue because these cropping systems are typically inundated for the majority of the growing season. $\mathrm{Zn}$ insufficiency worsens due to physicochemical parameters of soil, such as soil $\mathrm{pH}$ and $\mathrm{Zn}$ solubility (Nadeem \& Farooq, 2019). Humus in the soil binds Zn to its particles. Compost and charcoal use in agricultural soil can raise humic and fulvinic acid levels, lowering bioavailable Zinc (Li et al., 2019). Organic manure applied in an indiscriminate manner can reduce $\mathrm{Zn}$ bioavailability by forming insoluble compounds with $\mathrm{Zn}$ and altering soil $\mathrm{pH}$. Substantial use of pig dung reduced the $\mathrm{Zn}$ concentration of Brazilian soil (Benedet et al., 2020).

\section{Seed priming}

The embryo enclosed within a seed is a future plant. The resources given to a seed can increase the ability of the plant to become successful in its realised niche. Seed priming is a promising technology, to improve the performance in field and nutritional status of crops. In nutripriming, seeds are soaked in a solution containing nutrients to start pregerminative metabolic events without radical protrusion, after which seeds are dried closer to their original weight (Farooq et al., 2019).

Seed treatment or seed invigoration can be achieved by two methods: seed coating and seed priming or nutripriming. In seed coating, a more or less continuous layer of finely ground solids or liquids containing dissolved or suspended solids is covered all over the seed. In nutripriming, seeds are primed with nutrients by soaking in an appropriate nutrient solution for a specific duration of time (Farooq et al., 2019). By the technique of nutripriming, along with the nutritional advantages, biochemical achievements of priming can also be realised (Lutts et al., 2016). It helps the crop to meet its micronutrient requirements and improves germination, seedling emergence, stand establishment, yield, grain micronutrient quantity (Haider et al., 2020; Imran et al., 2015), resistance to abiotic and biotic stresses (Cabot et al., 2019; Rehman et al., 2012).

When compared to foliar spray and soil application, the benefits of nutripriming are numerous. The majority of fertilisers are mined, and these sources are limited. There is also environmental concern, as mining pollutes the environment (da Cruz et al., 2019). When nutrients are added to soil, they must pass through multiple huddles created by the soil's physicochemical qualities in order to reach the plant. Foliar spray can be used to get rid of the huddles that soil creates. However, the quantity required is large, and it must be sprayed at regular intervals of growth phases, and phytotoxicity is a serious worry. However, neither of these strategies can overcome the non-synchronised emergence of seeds, which is a key obstacle faced by changing environment and nutrient deficiency in seeds. Nutripriming can help to overcome all of these issues.

Nutripriming is less expensive and uses less nutrients, making it both cost-effective and environmentally beneficial. It can also aid in the uniform emergence and stand establishment of seedlings, stress tolerance as well as improve quality and quantity of yields (Majda et al., 2019). The concentration and duration of nutripriming are two essential characteristics that influence it and it varies from crop to crop, depending on its genetic makeup. Priming in larger concentrations for longer periods of time resulted in a decrease in growth metrics in most crops, possibly due to phytotoxic effects (Nciizah et al., 2020). As a result, preliminary research must be conducted to determine the optimal nutrient content and duration for improving crop growth, production and quality.

\section{Various sources of $\mathrm{Zn}$ for nutripriming}

The various $\mathrm{Zn}$ sources used in seed priming include inorganic $\mathrm{Zn}$ sources, organic $\mathrm{Zn}$ sources, chelated $\mathrm{Zn}$ sources and $\mathrm{Zn}$ nanoparticles (Zn-NP). The inorganic source includes zinc sulphate $\left(\mathrm{ZnSO}_{4}\right)$, zinc sulphate heptahydrate $\left(\mathrm{ZnSO}_{4} \cdot 7 \mathrm{H}_{2} \mathrm{O}\right)$, zinc chloride $\left(\mathrm{ZnCl}_{2}\right)$, 
zinc nitrate $\left(\mathrm{ZnNO}_{3}\right)$, zinc carbonate $\left(\mathrm{ZnCO}_{3}\right)$ and zinc oxide ( $\mathrm{ZnO})$. $\mathrm{ZnSO}_{4}$ and $\mathrm{ZnSO}_{4} .7 \mathrm{H}_{2} \mathrm{O}$ is the most commonly used priming agents due to its solubility, less reactivity soil components and cheaper rate. The most common synthetic chelated form of $\mathrm{Zn}$ is $\mathrm{Zn}$ EDTA, wherein the metal ion is coordinated with the chelating agent (Fig. 1). The quantity of soluble part of $\mathrm{Zn}$ present in all the above compounds varies (Naik \& Das, 2007; Ostad-Ali-Askari et al., 2017). The synthetic Zn chelators have many ill effects like low biodegradability, quick photodegradability and release of toxic agents on application in high amounts. It is also costly. So organic $\mathrm{Zn}$ chelators like $\mathrm{Zn}$ amino acids are also acquiring prominence as a priming agent. $\mathrm{Zn}$ amino acid complexes such as $\mathrm{Zn}(\mathrm{His})_{2}$, $\mathrm{Zn}(\mathrm{Met})_{2}, \mathrm{Zn}(\mathrm{Gln})_{2}, \mathrm{Zn}(\mathrm{Gly})_{2}, \mathrm{Zn}(\mathrm{Arg})_{2}$ are commonly used for priming (Mirbolook et al., 2020).

Nanoparticles are attaining attraction nowadays as they have many superior characteristics when compared to the traditional sources of nutrients. Some of such traits are their high surface area-to-volume ratio, high stability, high adsorption, increased surface reactivity, etc. Thus, a low dosage of application can have a visual impact on increased growth, yield and biofortification of crops (Mittal et al., 2020; Rastogi et al., 2017). The zinc nanoparticle (Zn NP) is one of the widely used NP in agricultural sector. It can be synthesised chemically by using chemical reagents (Neto et al., 2020) or biologically with the aid of microorganisms (Sabir et al., 2020) or plant extracts (Sabir et al., 2014). When used for priming and biofortification, the cost-effectiveness as well as the overall activity and effectiveness are usually considered before selecting a $\mathrm{Zn}$ source as a good priming agent.

\section{Effect of $\mathrm{Zn}$ enrichment in plants}

Seed priming influences plants positively and helps the plant to tide over the hazards and difficulties that it encounters during its life cycle. At every stage of the life cycle, priming has significant influence and it helps the plant to attain its biotic potential. Zn nutripriming has beneficial impact on germination parameters, seedling establishment, various yield attributes and $\mathrm{Zn}$ content in edible tissues (Farooq et al., 2012), and also many metabolic processes get stimulated (Gupta et al., 2016). The use of nutriprimed seeds in Zn-deficient soils are more efficient, as seeds with high $\mathrm{Zn}$ content perform better in $\mathrm{Zn}$-deficient soil than seeds with a smaller Zn content (Cakmak \& Kutman, 2018). There is a trend of increase in $\mathrm{Zn}$ content in edible portions on increasing the seed treatment concentrations of $\mathrm{Zn}$. But at higher concentrations, germination and growth are inhibited due to phytotoxicity. Thus, before considering a priming concentration genotoxic studies must be done. One such approach is to study the genotoxicity, by analysing the mitotic index and nucleolar activity of root tips (Carvalho et al., 2019; Reis et al., 2018).

Zinc in germination and seedling establishment

Seed priming increased the germination rate, reduced mean germination time and provided synchronised germination and early establishment of seedlings in crop plants. When mungbean seeds were nutriprimed for $6 \mathrm{~h}$ in $0.1 \mathrm{M} \mathrm{ZnSO} 4$ solution, germination increased by $53 \%$ when sown in a sandy loam soil with an alkaline $\mathrm{pH}$ of 8 (Haider et al., 2020). This may be due to the involvement of $\mathrm{Zn}$ in activating many enzymes needed for key metabolism like those involved in anaerobic respiration like alcohol dehydrogenase and is also crucial for the production of proteins (Cakmak \& Kutman, 2018). During seed priming, the supplied $\mathrm{Zn}$ is efficiently transported to the inner regions of the seed from the husk, increasing its availability to the region where it is required the most. This can be visualised by dithizone (DTZ) staining of seeds. When rice grains were treated with this stain, regions with $\mathrm{Zn}$ showed red colour and the intensity increased proportionally with the increase in Zn concentration (Prom-u-thai et al., 2012). This is because DTZ, a Zn chelating agent on reacting with Zn forms $\mathrm{Zn}$-dithizone complex which is red in colour (Durate et al., 2016).

$\mathrm{Zn}$-induced auxin production may be the reason for cell elongation and cell division, thus helping in root and shoot elongation. The distribution of $\mathrm{Zn}$ in coleoptile and radicle gives further proof for this. On germination, $\mathrm{Zn}$ present in the seeds is mobilised to growing regions of coleoptile and radicle and gets concentrated more at the tips. This feature shows the requirement of $\mathrm{Zn}$ in enzymes, carbohydrate metabolism as well as in transcription and translation, thus aiding in the increase in various growth parameters (Broadley et al., 2011; Ozturk et al., 2006). During 


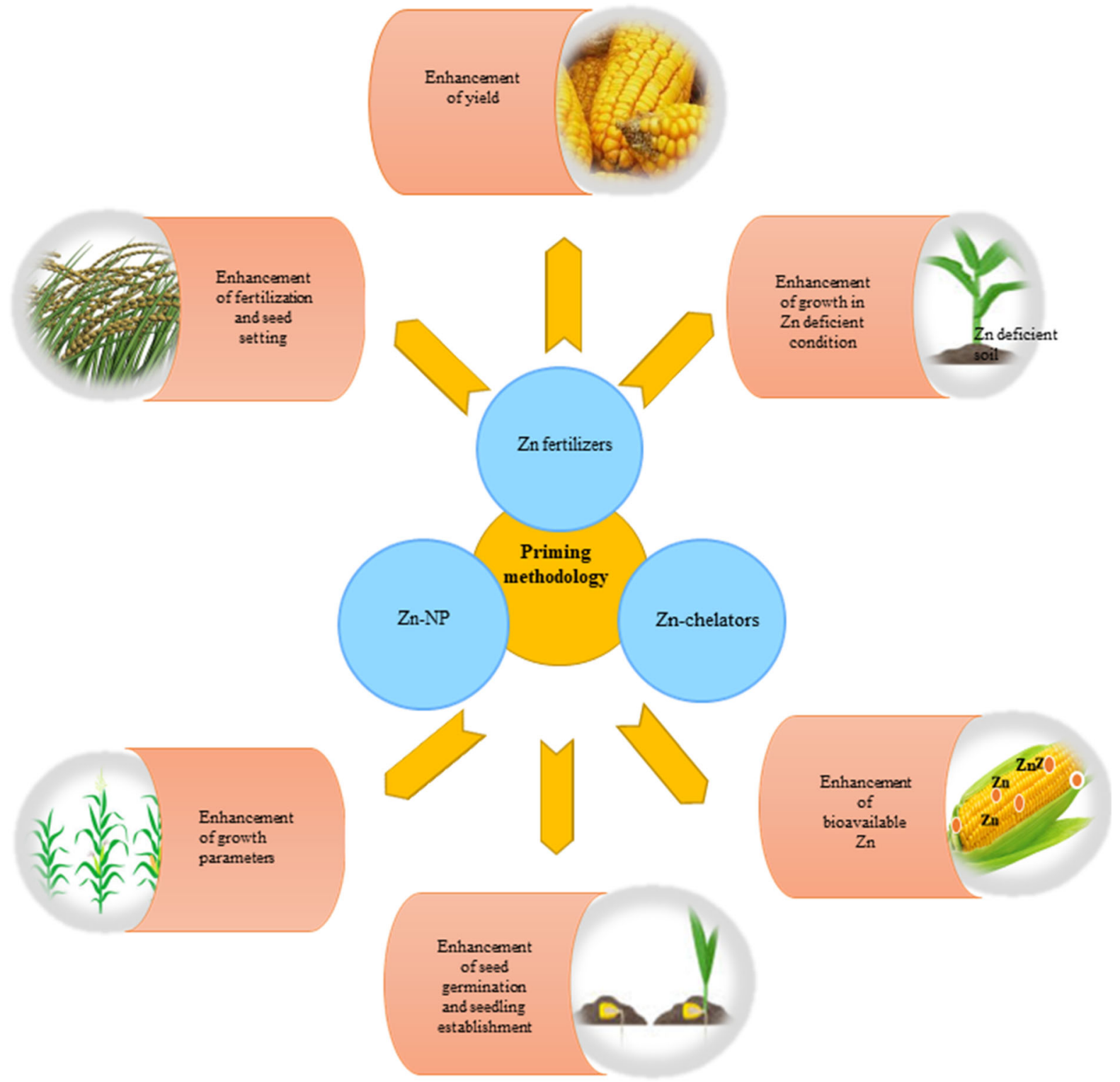

Fig. 1 Effect of $\mathrm{Zn}$ nutripriming in plants

DNA replication for the formation of initiation complex and replication fork, MINICHROMOSOME MAINTENANCE (MCM) proteins are needed. They possess various domains including a zinc finger domain for their activity. Along with this protein, several other proteins with $\mathrm{Zn}$ finger domain are also necessary for replication (Shultz et al., 2007). Also during cell division $\mathrm{Zn}$ is necessary for the polymerisation and stability of microtubules (Domart et al., 2020).
Transcription factors regulate gene expression and thus have role in development, signal transduction and metabolism. GATA Zn transcription factors are DNA binding proteins which regulate various developmental processes in plants including flower development (Zhu et al., 2020). The role of GATA Zn finger transcription factor, BLUE MICROPYLAR END 3 (BME3) in breaking seed dormancy, is well documented in Arabidopsis plant. It positively influences the transition from dormancy to germination, by enabling the radicle to come out by resisting the 
various mechanical constrains that block germination. This can be correlated with the observation that seeds with malfunctioned BME3 showing deeper dormancy when compared with the normal populations (Liu et al., 2005). On priming the seeds with $\mathrm{Zn}$, this metal may possibly influence this transcription factor and thereby enhance the germination parameters.

During germination ROS are produced continuously as a result of the metabolic activities occurring in mitochondria, peroxisomes, glyoxysomes and chloroplast. Although ROS accumulation can be harmful, low levels of the same can provide disease resistance, apoptosis of aleurone layer, deterioration of endosperm, cell signalling and maintenance of redox potential. The level of ROS should be maintained between a threshold level called "oxidative window" for breaking the seed dormancy. Below it, the seed will remain in dormant stage, and above this level, it results in production of anomalous seedlings. Thus, in order to break dormancy and increasing the seed vigor, the cell's antioxidant machineries should perform perfectly and flawlessly. Hence, Zn-containing SOD and catalase enzymes appear to help the seed to increase its vigor by controlling the ROS levels (Ma et al., 2017). The possible role of $\mathrm{Zn}$ in germination is illustrated in Fig. 2.

Zinc in yield, yield-related traits and $\mathrm{Zn}$ accumulation in edible parts

The efficacy of $\mathrm{Zn}$ in promoting the grain yield and yield components can be inferred by analysing the productive panicle number, grains per panicle and grain weight. Through seed treatments with $\mathrm{Zn}$, all these attributes can be increased (Farooq et al., 2018). In Zn-deficient soil, nutripriming of maize plants in the optimum concentration and time with $\mathrm{ZnSO} 4$ solution enhanced the yield by $27 \%$ (Harris et al., 2007). In a field research done in Faisalabad and Sialkot, $\mathrm{ZnSO} 4$ primed seeds enhanced the yield by $31 \%$ and $40 \%$, respectively (Farooq et al., 2018). The use of $\mathrm{ZnSO} 4$ solution to prime the rice seeds enhanced the output by 23\%. (Zulfiqar et al., 2020). In the case of chickpea, priming with $\mathrm{ZnSO} 4$ solution improved the yield by $24 \%$ and $15 \%$ in the desi and kabuli varieties, respectively (Ullah et al., 2020). Zn seed priming was the most efficient strategy for increasing wheat grain production in rice-wheat cropping systems, increasing output by 56 per cent in conventional tillage and 60 per cent in conservation tillage (Nadeem et al., 2020). The reason behind this can be deduced by the fact that $\mathrm{Zn}$ is necessary for the pollen tube growth and fertilisation by facilitating pollen-stigma interaction (Pandey et al., 2006). For effective fertilisation and seed setting, the pollen from the androecium has to reach the female gametophyte present in the gynoecium, and for this the pollen tube grows and moves through the transmission tract of the style. The extracellular space needed for the pollen tube growth is produced by programmed cell death (PCD), the NO TRANSMITTING TRACT gene encoding a $\mathrm{C} 2 \mathrm{H} 2 / \mathrm{C} 2 \mathrm{HC}$ zinc finger transcription factor facilitates this (Cascallares et al., 2020). In addition to this, the movement is also facilitated by the expression of CENTRAL CELL GUIDANCE (CCG) gene encoding a transcription factor with a conserved $\mathrm{N}$ terminal zinc $\beta$-ribbon domain in the central cell of the mature female gametophyte (Chen et al., 2007; Li \& Yang, 2020; Wang et al., 2010). Thus, Zn has a prominent role in effecting the fertilisation and seed set.

The greater growth attributes reflected in plants as a result of $\mathrm{Zn}$ are due to the involvement of $\mathrm{Zn}$ in photosynthesis. Carbonic anhydrase, a Zn metalloenzyme, shows pivotal role in photosynthetic organisms as it is crucial for the activity of the enzyme Rubisco. Carbonic anhydrase catalyses the reversible conversion of bicarbonate to $\mathrm{CO}_{2}$, the substrate needed for Rubisco (Dimario et al., 2017; Qiao et al., 2014). Thus, the role of $\mathrm{Zn}$ in the activity of carbonic anhydrase and the indirect influence in the rate of photosynthesis is evident by the decrease in carbonic acid concentration, carbonic anhydrase mRNA as well as photosynthetic rate during Zn-deficient condition (Sasaki et al., 1998; Polishchuk et al., 2021). The aspects discussed above are illustrated in the fig. 2.

Aldolase, a $\mathrm{Zn}$-dependent enzyme, is vital for growth and development of all organisms including plants. It plays an essential role in carbohydrate metabolisms by catalysing key reactions in reductive pentose phosphate cycle, metabolic processes such as Embden-Meyerhof-Parnas (EMP) pathway and gluconeogenesis (Lv et al., 2017). Hence, it can be inferred that this enzyme assists in enhancing photosynthetic capacity, growth rate and thus biomass increase by hastening the regeneration of RuBP. The most important part of the seed is embryo, and it is equipped with all the factors needed for germination and survival. As a result, this propagule is a store 


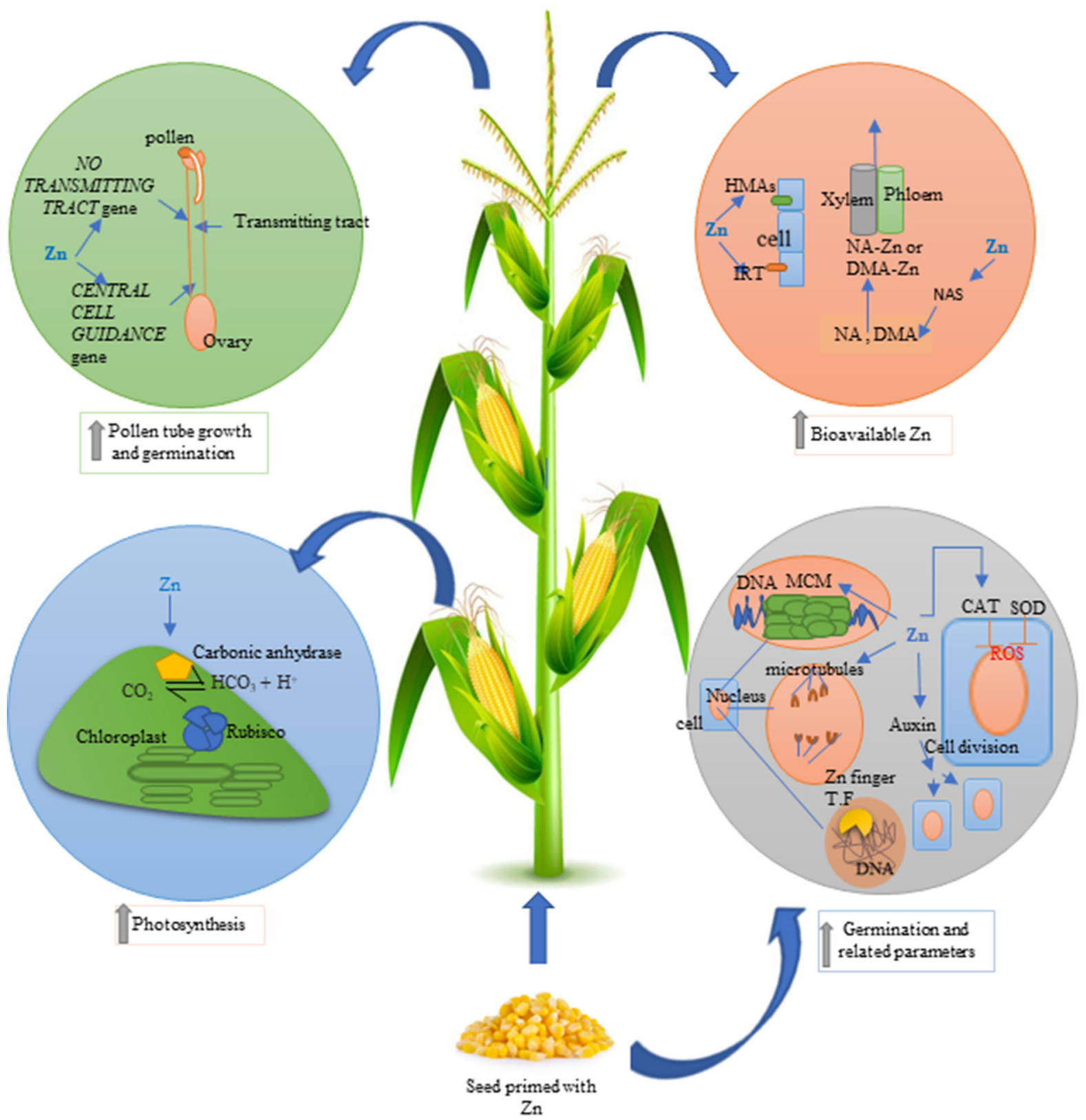

Fig. 2 Possible role of $\mathrm{Zn}$ in nutriprimed plants. The possible role of $\mathrm{Zn}$ in pollen tube growth, in increasing bioavailability of $\mathrm{Zn}$, increasing growth of the plant by influencing photosynthesis and increasing seed germination. Abbreviations: Zn-zinc,

house of essential minerals like $\mathrm{Zn}$ needed for the activation of enzymes, light harvesting and turgor maintenance needed during germination ( $\mathrm{Lu}$ et al., 2013).
HMAs-heavy metal ATPase, IRT-iron-regulated transporter, MCM-MINICROMOSOME MAINTAINANCE protein, CATcatalase, SOD-superoxide dismutase, ROS-reactive oxygen species, T.F-transcription factor

Possible roles of priming in influencing the increase in $\mathrm{Zn}$ level in plants

To fulfill any biofortification approach, a thorough knowledge of the transporter system is very essential. Transporter proteins are necessary for the 
translocation of metal ions into and out of the cell, microcompartments and for sequestering these ions in vacuoles to act as a reservoir or to reduce toxicity. Mainly three transporter systems are elucidated for $\mathrm{Zn}$ transport. They are the ZIP (zinc-iron permease or ZRT, IRT-like proteins) family of transporters seen on plasma membrane. The CDFs (cation diffusion facilitator) like MTPs (metal tolerance protein), seen on tonoplasts and HMAs (heavy metal ATPase) a P-type ATPase, localised on plasma membrane, tonoplast and endomembrane system (Caroli et al., 2020).

On seed invigoration (seed priming or seed coating) with $\mathrm{Zn}$, an increase in yield factors was noticed, which may be due to increased expression of $\mathrm{Zn}$ transporters like HMAs. There is evidence for the expression of HMAs (HMA9) transporter proteins in anther of rice and Arabidopsis on application of $\mathrm{Zn}$. The increased $\mathrm{Zn}$ in anther has many positive aspects such as increased pollen fertilisation and seed set as discussed earlier. Thus, it could be concluded that these transporters translocate $\mathrm{Zn}$ into androecium to bring about increase in yield parameters (Lee et al., 2007). This can be confirmed by the male sterility of nas4x-2 mutant line of Arabidopsis during Zn deficiency. In these mutants, the nicotinamine (NA) was completely absent, affecting NA-mediated transportation of $\mathrm{Zn}$ to anthers via the transporters (Schuler et al., 2012).

BRUTUS (BTS) a Zn-containing protein is able to regulate the expression of genes needed for $\mathrm{Zn}$ translocation and accumulation. BTS is an E3 ubiquitin ligase characterised by having a $\mathrm{Zn}$ finger protein domain. This ubiquitin ligase can add ubiquitin and regulate FER-LIKE DEFICIENCY-INDUCED TRANSCRIPTION FACTOR (FIT) transcription factor which aids in the expression of genes needed for $\mathrm{Fe}$ uptake and the genes for the transporters like IRT. Along with $\mathrm{Fe}$, non-specific uptake of $\mathrm{Zn}$ also takes place through this transporter (Long et al., 2010). FIT can also regulate the expression of NICOTINAMINE SYNTHASE (NAS) genes (Rodríguez-Celma et al., 2019). The NAS synthesises low molecular weight chelators like nicotinamine (NA) and deoxymugeieic acid (DMA) which can chelate Zn. The Zn-NA complex thus formed aid in long distance transport of $\mathrm{Zn}$ via xylem and phloem into the seed (Clemens et al., 2013; Lee et al., 2011). The plant cadmium resistance 1 (PCR1) is a transmembrane protein aiding the translocation of $\mathrm{Zn}$. In rice, it is present in roots at seedling stage, on reproductive stage seen on I and II internodes and on spikelet. Hence it can be proposed that this transporter may also have role in $\mathrm{Zn}$ accumulation in grains (Song et al., 2015). Therefore, during seed priming this metal can certainly regulate the key genes discussed above reflecting in biofortification. The possible role of $\mathrm{Zn}$ nutripriming in increasing the $\mathrm{Zn}$ in edible tissues is discussed in Fig. 2.

\section{Achievements of $\mathrm{Zn}$ biofortification through nutripriming}

Seed priming with $\mathrm{ZnSO}_{4}$ solution increased the yield and yield-related traits and grain $\mathrm{Zn}$ content in barley and wheat. However, an increase in concentration and time of application has negative effect on the growth and yield. This may be due to the cytotoxic effect of high concentration of $\mathrm{Zn}$. Seed priming as well as seed coating of two varieties of wheat with $\mathrm{ZnSO}_{4} 7 \mathrm{H}_{2} \mathrm{O}$ increased the stand establishment, emergence, yield and yield-related traits, and also grain $\mathrm{Zn}$ content in continuous two seasons of experiments (Hassan et al., 2019). In three wheat varieties, different types of $\mathrm{Zn}$ amino acid chelate were used to study the effect on growth, yield and biofortification efficiency. The biofortification efficiency of each varied with the source of $\mathrm{Zn}$ and genetic makeup of the wheat variety. The different $\mathrm{Zn}$ amino acid chelates used were $\mathrm{Zn}$ histidine [Zn (His) $)_{2}$, Zn-glutamine [Zn $\left.(\mathrm{Gln})_{2}\right]$, Znarginine [Zn $\left.(\mathrm{Arg})_{2}\right]$ and $\mathrm{Zn}$-glycine [Zn $\left.(\mathrm{Gly})_{2}\right]$. When compared to other priming agents, and soil application of $\mathrm{Zn}$ fertilisers, Zn-histidine and $\mathrm{Zn}$ arginine increased grain $\mathrm{Zn}$ content (Seddigh et al., 2016). Seed priming with $\mathrm{ZnSO}_{4}$ and $\mathrm{ZnCl}_{2}$ in sugar beet increased the $\mathrm{Zn}$ concentration, making it a potential biofortification candidate. From this study, the $\mathrm{Zn}$ level increase achieved through $\mathrm{Zn}$ seed priming could be correlated with the increase in photosynthetic rate, transpiration and stomatal conductance of the plant (Carmona et al., 2020). Seed invigoration by priming and coating of chickpea with $\mathrm{ZnSO}_{4}$ increased the bioavailable grain $\mathrm{Zn}$ content along with the yield and yield-related traits (Ullah et al., 2020).

Farooq and co-workers (2018) studied the yield and grain $\mathrm{Zn}$ content of aromatic rice grain based on various $\mathrm{Zn}$ application methods including seed 
priming and seed coating in direct seeded and transplanted rice production systems. Even though there were no marked differences in yield among the treatments, there were considerable differences in grain $\mathrm{Zn}$ content. When compared to seed coating, seed priming was more effective in increasing the grain $\mathrm{Zn}$ content (Farooq et al., 2018). On calcareous soils, seed priming of rice with $0.5 \% \mathrm{ZnSO}_{4}$ solution could increase grain $\mathrm{Zn}$ content, when compared to control plants without any $\mathrm{Zn}$ treatment (Imran et al., 2015).

Seed priming with $\mathrm{Zn}$ is a good option to increase growth, yield parameters and grain $\mathrm{Zn}$ content of mungbean (Vigna radiata (L.) Wilczek) (Haider et al., 2020). Field trails of wheat and chickpea, using $\mathrm{ZnSO}_{4}$ as a priming agent, increased the grain $\mathrm{Zn}$ content (Harris et al., 2007). A comparative study of different modes of $\mathrm{Zn}$ treatments in maize was done to identify the potential of each method for biofortification. The results showed that seed coating method was more effective in increasing the grain $\mathrm{Zn}$ content (Ladumor et al., 2019). Seeds of two cultivars of common bean "Sadri" and "Talash" were considered to analyse the influence of $\mathrm{Zn}$ amino acid synthetic chelators like $\mathrm{Zn}$ methionine $\left[\mathrm{Zn}(\mathrm{Met})_{2}\right]$ and $\mathrm{Zn}$-histidine $\left[\mathrm{Zn}(\mathrm{His})_{2}\right]$ over soil applied $\mathrm{Zn}$ fertilisers. The analysis revealed that $\mathrm{Zn}(\mathrm{Met})_{2}$ was more efficient in increasing the seed $\mathrm{Zn}$ content in "Sadri" cultivar while the $\mathrm{Zn}(\mathrm{His})_{2}$ was more efficient in "Talash" cultivar. Seed priming using [ $\mathrm{Zn}$ (His)2] and [ $\mathrm{Zn}$ (Met)2] increased the grain $\mathrm{Zn}$ concentration by $8.5-33.8$ per cent and $16.5-34.3$ per cent, respectively, as compared to the priming with $\mathrm{ZnSO}_{4}$ (Tabesh et al., 2020). And it was clearly evident that $\mathrm{Zn}$ amino acid synthetic chelators gave better results than $\mathrm{Zn}$ fertilisers.

When compared to priming using $\mathrm{ZnSO}_{4}$ as an application, ZnO-NP increased the germination, yield and biofortification of ragi (Rameshraddy et al., 2017). The combined action of $\mathrm{ZnO}-\mathrm{NP}$ and $\mathrm{FeO}-\mathrm{NP}$ increased nutritional factors and $\mathrm{Zn}$ in ragi (Mahmoud et al., 2019). This shows that $\mathrm{Zn}$-based nanoparticles can bring about more positive effect of $\mathrm{Zn}$ biofortification. Seed priming with Zn-NP can increase the concentration of various amino acids such as glutamate and glycine, which helps in metabolism and chlorophyll synthesis and thus can improve the growth aspects as well as the nutritional status of the plants (Salama et al., 2019). In general, there are very less literature available on the usage of NP for the nutripriming of seeds. In future, the technology of NP may play a significant role in achieving the biofortification of important crops. Zn nutripriming with Zn-NP requires only less quantity of NPs for application, and at the same time, it can show all the potential superior qualities, and hence, it will be more cost-effective and a clean technology when compared to other methods. Biofortification approaches for $\mathrm{Zn}$ through seed invigoration (seed priming and coating) techniques in various crops are enlisted in Table 1.

\section{Conclusion}

Micronutrient malnutrition is now recognised as a serious health and economic issue in the world, as it negatively affects the socioeconomic status of the country. Thus, it is high time to shift our agricultural practices to ensure nutrient enrichment in food grains. Zinc malnutrition is common in developing countries, due to dependence on a monotonous diet based on $\mathrm{Zn}$ deficient staple food crops. The alternative approaches to meet the dietary requirement of $\mathrm{Zn}$, like food fortification, diet diversification, $\mathrm{Zn}$ supplementation cannot be realised in these impoverished communities. The foremost method to alleviate $\mathrm{Zn}$ malnutrition in these regions is to biofortify the major food staple crops. Various methods of biofortification are agronomic approach, breeding and transgenic approaches. Seed invigoration including seed priming and seed coating is cost-effective, eco-friendly methods of biofortification. Because each plant reacts differently to each priming agent, the correct priming agent and application dosage must be standardised first. The priming agent may be hazardous to plants at high concentrations; hence, the optimal concentration has to be experimented to determine the priming agent's genotoxic dosage. No single intervention can alleviate all of the issues associated with micronutrient malnutrition; all interventions, in conjunction with state policy, should work together to address the effects of hidden hunger and bring about a viable solution.

\section{Future prospects}

Biofortification of crops with $\mathrm{Zn}$ needs a deeper knowledge of physiological, biochemical and molecular mechanisms of $\mathrm{Zn}$ transportation and activity of 


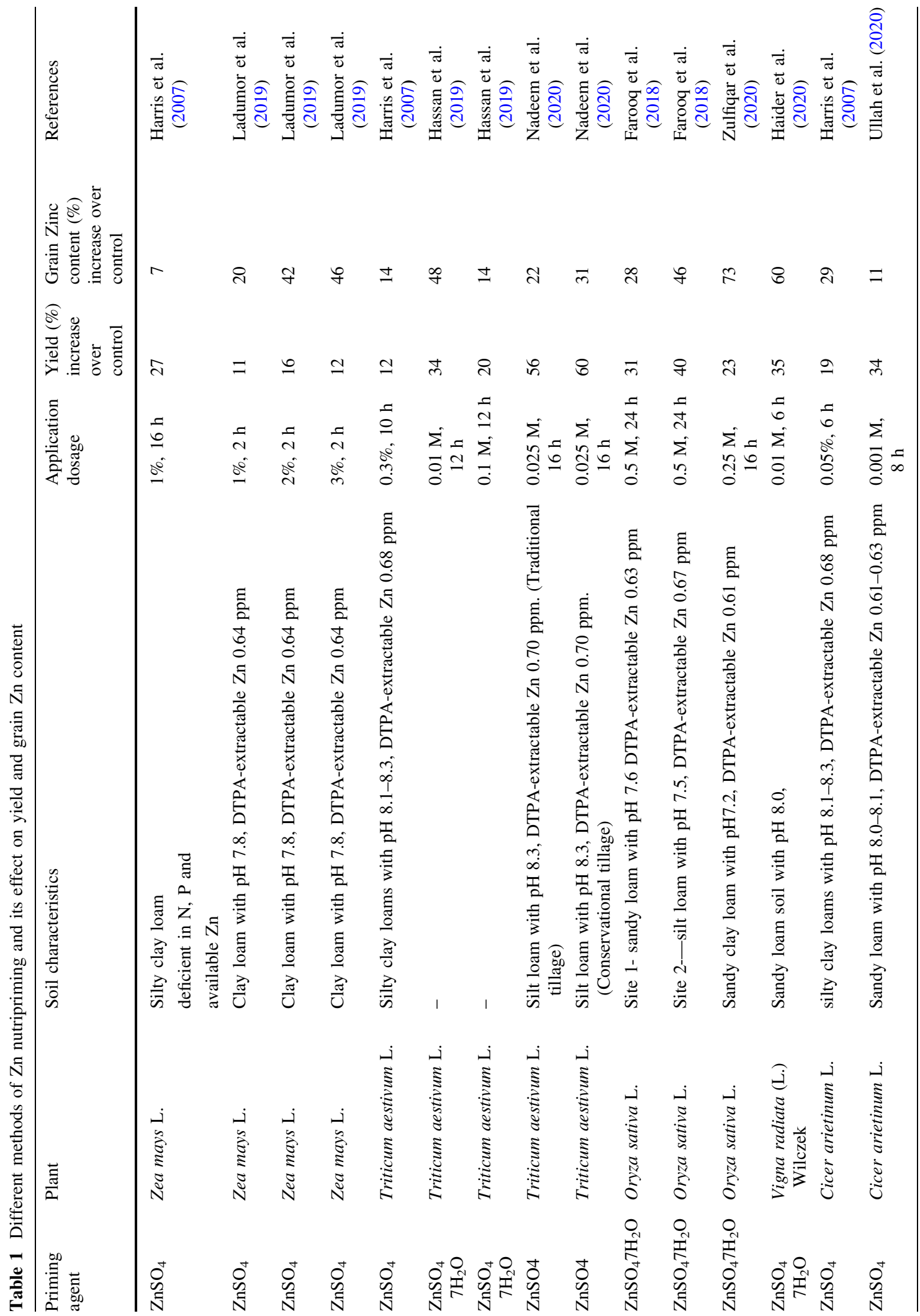


$\mathrm{Zn}$ in cells. Research has to be focused to identify all the $\mathrm{Zn}$ transporters and to carry out their molecular and physiological characterisation. The regulation of proteins involved in $\mathrm{Zn}$ accumulation should be studied at transcriptional and post translational level. Cadmium, a toxic analogue, may accumulate, as many of the $\mathrm{Zn}$ transporters can transport $\mathrm{Cd}$ in lieu of $\mathrm{Zn}$. Research should be directed towards the possibility of $\mathrm{Zn}$ accumulation in preference to $\mathrm{Cd}$. There are many $\mathrm{Zn}$ compounds used for priming, each crop responds differently to each source, so research must be done to find the appropriate priming agent and dosage for each crop. Zn-NP is a potential agent for biofortification, and research must be also done to find a clean and green nanoparticle which is highly efficient. Epigenetic analysis also has to be done to study the retention of priming memory and the genetic changes in continuous generations, that is, imparted by nutripriming with $\mathrm{Zn}$ compounds.

Acknowledgements MV acknowledges University grant commission (UGC), India, for providing funding in the form of JRF. The authors also acknowledge the Department of Science \& Technology (DST), Government of India, for granting fund under Fund for Improvement of $\mathrm{S} \& \mathrm{~T}$ Infrastructure (FIST) programme

(DST-FIST/15-16/ 28.05.2015).

Author contributions VM wrote the manuscript; JTP designed and corrected the manuscript.

Funding This work was supported by the University grant commission (UGC), India, by providing funding in the form of JRF. Department of Science \& Technology (DST), Government of India, granted fund under Fund for Improvement of S\&T Infrastructure (FIST) programme (SR/FST/LSI-532/2012).

Availability of data and material Not applicable.

Code availability Not applicable.

\section{Declarations}

Conflict of interest The authors declare that they have no conflict interest.

\section{References}

Akhtar, M., Yousaf, S., Sarwar, N., \& Hussain, S. (2019). Zinc biofortification of cereals-role of phosphorus and other impediments in alkaline calcareous soils. Environmental Geochemistry and Health,41(5), 2365-2379. https://doi. org/10.1007/s10653-019-00279-6
Alloway, B. J. (2009). Soil factors associated with zinc deficiency in crops and humans. Environmental Geochemistry and Health, 31, 537-548. https://doi.org/10.1007/s10653009-9255-4

Andresen, E., Peiter, E., \& Küpper, H. (2018). Trace metal metabolism in plants. Journal of Experimental Botany, 69(5), 909-954. https://doi.org/10.1093/jxb/erx465

Atar, B., Uygur, V., \& Sukuşu, E. (2020). Effects of priming with Copper, Zinc and Phosphorus on seed and seedling composition in Wheat and Barley. Turkish Journal of Agricultural and Natural Sciences, 7(1), 104-111. https:// doi.org/10.30910/turkjans.680021

Bailey, R. L., West, K. P., \& Black, R. E. (2015). The epidemiology of global micronutrient deficiencies. Annals of Nutrition and Metabolism, 66, 22-33. https://doi.org/10. 1159/000371618

Barak, P., \& Helmke, P. A. (1993). The chemistry of zinc. In A. D. Robson (Ed.), Zinc in soils and plants . Springer. https:// doi.org/10.1007/978-94-011-0878-2_1

Baran, A., Wieczorek, J., Mazurek, R., Urbański, K., \& Klimkowicz-Pawlas, A. (2018). Potential ecological risk assessment and predicting zinc accumulation in soils. Environmental Geochemistry and Health, 40(1), 435-450. https://doi.org/10.1007/s10653-017-9924-7

Benedet, L., Dick, D. P., Brunetto, G., dos Santos Júnior, E., Ferreira, G. W., Lourenzi, C. R., \& Comin, J. J. (2020). Copper and $\mathrm{Zn}$ distribution in humic substances of soil after 10 years of pig manure application in south of Santa Catarina, Brazil. Environmental Geochemistry and Health, 42(10), 3281-3301. https://doi.org/10.1007/s10653-02000572-9

Broadley, M., Brown, P., Cakmak, I., Rengel, Z., \& Zhao, F. (2011). Function of nutrients: micronutrients. In P. Marschner (Ed.), Marschner's mineral nutrition of higher plants (3rd ed.). Berlin: Elsevier. https://doi.org/10.1016/ B978-0-12-384905-2.00007-8

Broadley, M. R., White, P. J., Hammond, J. P., Zelko, I., \& Lux, A. (2007). Zinc in plants. New Phytologist, 173(4), 677-702. https://doi.org/10.1111/j.1469-8137.2007. 01996.x

Cabot, C., Martos, S., Llugany, M., Gallego, B., Tolrà, R., \& Poschenrieder, C. (2019). A role for zinc in plant defense against pathogens and herbivores. Frontiers in Plant Science, 10, 1171. https://doi.org/10.3389/fpls.2019.01171

Cakmak, I. (2000). Possible roles of zinc in protecting plant cells from damage by reactive oxygen species. New Phytologist, 146, 185-205.

Cakmak, I., \& Kutman, U. B. (2018). Agronomic biofortification of cereals with zinc: A review. European Journal of Soil Science, 69(1), 172-180. https://doi.org/10.1111/ejss. 12437

Carmona, V. M. V., Filho, A. B. C., de Almeida, H. J., Silva, G. C., \& dos Reis, A. R. (2020). Agronomic biofortification of beet plants with zinc via seed priming. Revista Caatinga, 33(1), 116-123. https://doi.org/10.1590/198321252020v33n113rc

Caroli, M., Furini, A., DalCorso, G., Rojas, M., \& di Sansebastiano, G. P. (2020). Endomembrane reorganization induced by heavy metals. Plants, 9(4), 482. https://doi.org/ 10.3390/plants 9040482 
Carvalho, A., Reis, S., Pavia, I., \& Lima-Brito, J. E. (2019). Influence of seed priming with iron and/or zinc in the nucleolar activity and protein content of bread wheat. Protoplasma, 256(3), 763-775. https://doi.org/10.1007/ s00709-018-01335-1

Cascallares, M., Setzes, N., Marchetti, F., López, G. A., Distéfano, A. M., Cainzos, M., Zabaleta, E., \& Pagnussat, G. C. (2020). A complex journey: Cell wall remodeling, interactions, and integrity during pollen tube growth. Frontiers in Plant Science, 11, 599247. https://doi.org/10. 3389/fpls.2020.599247

Chanfreau, G. F. (2013). Zinc'ing down RNA polymerase i. Transcription, 4(5), 217-220. https://doi.org/10.4161/trns. 26594

Chasapis, C. T., Ntoupa, P. S. A., Spiliopoulou, C. A., \& Stefanidou, M. E. (2020). Recent aspects of the effects of zinc on human health. Archives of Toxicology, 94(5), 1443-1460. https://doi.org/10.1007/s00204-020-02702-9

Chen, X. X., Zhang, W., Wang, Q., Liu, Y. M., Liu, D. Y., \& Zou, C. Q. (2019). Zinc nutrition of wheat in response to application of phosphorus to a calcareous soil and an acid soil. Plant and Soil, 434(1), 139-150. https://doi.org/10. 1007/s11104-018-3820-5

Chen, Y. H., Li, H. J., Shi, D. Q., Yuan, L., Liu, J., Sreenivasan, R., Baskar, R., Grossniklaus, U., \& Yang, W. C. (2007). The central cell plays a critical role in pollen tube guidance in Arabidopsis. The Plant Cell, 19(11), 3563-3577. https:// doi.org/10.1105/tpc.107.053967

Clemens, S. (2014). $\mathrm{Zn}$ and Fe biofortification: The right chemical environment for human bioavailability. Plant Science, 225, 52-57. https://doi.org/10.1016/j.plantsci. 2014.05.014

Clemens, S., Deinlein, U., Ahmadi, H., Höreth, S., \& Uraguchi, S. (2013). Nicotianamine is a major player in plant $\mathrm{Zn}$ homeostasis. BioMetals, 26(4), 623-632. https://doi.org/ 10.1007/s10534-013-9643-1

Czech, A., Zarycka, E., Yanovych, D., Zasadna, Z., Grzegorczyk, I., \& Kłys, S. (2020). Mineral content of the pulp and peel of various citrus fruit cultivars. Biological Trace Element Research, 193(2), 555-563. https://doi.org/10. 1007/s12011-019-01727-1

da Cruz, T. N., Savassa, S. M., Montanha, G. S., Ishida, J. K., de Almeida, E., Tsai, S. M., Junior, J. L., \& de Carvalho, H. W. P. (2019). A new glance on root-to-shoot in vivo zinc transport and time-dependent physiological effects of $\mathrm{ZnSO} 4$ and $\mathrm{ZnO}$ nanoparticles on plants. Scientific Reports, 9(1), 1-12. https://doi.org/10.1038/s41598-01946796-3

Das, A., Singh, S. K., Kumar, M., \& Kumar, O. (2018). Zinc biofortification: A novel strategy for improving human health. Journal of Experimental Biology and Agricultural Sciences, 6(5), 751-762.

Derwand, R., \& Scholz, M. (2020). Does zinc supplementation enhance the clinical efficacy of chloroquine/hydroxychloroquine to win today's battle against COVID-19? Medical Hypotheses, 142, 109815. https://doi.org/10.1016/ j.mehy.2020.109815

Dhaliwal, S. S., Naresh, R. K., Mandal, A., Singh, R., \& Dhaliwal, M. K. (2019). Dynamics and transformations of micronutrients in agricultural soils as influenced by organic matter build-up: A review. Environmental and
Sustainability Indicators, 1, 100007. https://doi.org/10. 1016/j.indic.2019.100007

DiMario, R. J., Clayton, H., Mukherjee, A., Ludwig, M., \& Moroney, J. V. (2017). Plant carbonic anhydrases: Structures, locations, evolution, and physiological roles. Molecular Plant, 10(1), 30-46. https://doi.org/10.1016/j. molp.2016.09.001

Domart, F., Cloetens, P., Roudeau, S., Carmona, A., Verdier, E., Choquet, D., \& Ortega, R. (2020). Correlating sted and synchrotron xrf nano-imaging unveils co segregation of metals and cytoskeleton proteins in dendrites. ELife, 9, 1-18. https://doi.org/10.7554/ELIFE.62334

Duarte, R. F., Prom-u-thai, C., Amaral, C. D., Faquin, V., Guilherme, G. R. L., Reis, R. A., \& Alves, E. (2016). Determination of zinc in rice grains using DTZ staining and ImageJ software. Journal of Cereal Science, 68, 53-58. https://doi.org/10.1016/j.jcs.2015.11.006

Farooq, M., Basra, S. M. A., Khalid, M., Tabassum, R., \& Mahmood, T. (2006). Nutrient homeostasis, metabolism of reserves, and seedling vigor as affected by seed priming in coarse rice. Canadian Journal of Botany, 84, 1196-1202. https://doi.org/10.1139/B06-088

Farooq, M., Ullah, A., Rehman, A., Nawaz, A., Nadeem, A., Wakeel, A., Nadeem, F., \& Siddique, K. H. M. (2018). Application of zinc improves the productivity and biofortification of fine grain aromatic rice grown in dry seeded and puddled transplanted production systems. Field Crops Research, 216, 53-62. https://doi.org/10.1016/j.fcr.2017. 11.004

Farooq, M., Usman, M., Nadeem, F., Rehman, H., Wahid, A., Basra, S. M. A., \& Siddique, K. H. M. (2019). Seed priming in field crops: Potential benefits, adoption and challenges. Crop and Pasture Science, 70, 731-771.

Farooq, M., Wahid, A., \& Siddique, K. H. M. (2012). Micronutrient application through seed treatments-a review. Journal of Soil Science and Plant Nutrition, 12(1), 125-142. 95162012000100011

Gammoh, N. Z., \& Rink, L. (2019). Zinc and the immune system. In M. Mahmoudi \& N. Rezaei (Eds.), Nutrition and Immunity (pp. 127-158). Springer.

Garg, M., Sharma, N., Sharma, S., Kapoor, P., Kumar, A., Chunduri, V., \& Arora, P. (2018). Biofortified crops generated by breeding, agronomy, and transgenic approaches are improving lives of millions of people around the world. Frontiers in Nutrition, 5, 12. https://doi.org/10.3389/fnut. 2018.00012

Gibson, R. S. (2012). Zinc deficiency and human health: Etiology, health consequences, and future solutions. Plant and Soil, 361(2), 291-299. https://doi.org/10.1007/s11104012-1209-4

Graham, R. D., Knez, M., \& Welch, R. M. (2012). How much nutritional iron deficiency in humans globally is due to an underlying zinc deficiency? In R. D. Sparks (Ed.), Advances in agronomy. Elsevier. https://doi.org/10.1016/ B978-0-12-394276-0.00001-9

Gregory, P. J., Wahbi, A., Adu-Gyamfi, J., Heiling, M., Gruber, R., Joy, E. J., \& Broadley, M. R. (2017). Approaches to reduce zinc and iron deficits in food systems. Global Food Security, 15, 1-10. https://doi.org/10.1016/j.gfs.2017.03. 003 
Gupta, N., Ram, H., \& Kumar, B. (2016). Mechanism of zinc absorption in plants: Uptake, transport, translocation and accumulation. Reviews in Environmental Science and Biotechnology, 15(1), 89-109. https://doi.org/10.1007/ s11157-016-9390-1

Gupta, S., Brazier, A. K. M., \& Lowe, N. M. (2020). Zinc deficiency in low-and middle-income countries: Prevalence and approaches for mitigation. Journal of Human Nutrition and Dietetics, 33(5), 624-643.

Hafeez, B., Khanif, Y. M., \& Saleem, M. (2013). Role of zinc in plant nutrition. American Journal of Experimental Agriculture, 3(2), 374-391.

Haider, M. U., Hussain, M., Farooq, M., \& Nawaz, A. (2020). Optimizing zinc seed priming for improving the growth, yield and grain biofortification of mungbean (Vigna radiata L. wilczek). Journal of Plant Nutrition, 43(10), 1438-1446. https://doi.org/10.1080/01904167.2020. 1730895

Harris, D., Rashid, A., Miraj, G., Arif, M., \& Shah, H. (2007). "On-farm" seed priming with zinc sulphate solution-A cost-effective way to increase the maize yields of resourcepoor farmers. Field Crops Research, 102(2), 119-127. https://doi.org/10.1016/j.fcr.2007.03.005

Hassan, N., Irshad, S., Saddiq, M. S., Bashir, S., Khan, S., Wahid, M. A., Khan, R. R., \& Yousra, M. (2019). Potential of zinc seed treatment in improving stand establishment, phenology, yield and grain biofortification of wheat. Journal of Plant Nutrition, 42(14), 1676-1692. https://doi. org/10.1080/01904167.2019.1630429

Heidari-Beni, M., Golshahi, J., Esmaillzadeh, A., \& Azadbakht, L. (2015). Potato consumption as high glycemic index food, blood pressure, and body mass index among Iranian adolescent girls. ARYA Atherosclerosis, 11(Suppl 1), 81.

Heidari-Beni, M., Riahi, R., Massoudi, S., Qorbani, M., \& Kelishadi, R. (2021). Association between dietary diversity score and anthropometric indices among children and adolescents: The weight disorders survey in the CASPIANIV study. Journal of the Science of Food and Agriculture. https://doi.org/10.1002/jsfa.11152

Hotz, C., \& Brown, K. H. (2004). International Zinc Nutrition Consultative Group (IZiNCG) Technical Document 1. Assessment of risk of zinc deficiency in population and options for its control. Food and Nutrition Bulletin, 25, 94-200. 75182010000200014

Huang, S., Wang, P., Yamaji, N., \& Ma, J. F. (2020). Plant nutrition for human nutrition: Hints from rice research and future perspectives. Molecular Plant, 13(6), 825-835. https://doi.org/10.1016/j.molp.2020.05.007

Impa, S. M., \& Johnson-Beebout, S. E. (2012). Mitigating zinc deficiency and achieving high grain $\mathrm{Zn}$ in rice through integration of soil chemistry and plant physiology research. Plant and Soil, 361(1), 3-41. https://doi.org/10.1007/ s11104-012-1315-3

Imran, M., Kanwal, S., Hussain, S., \& Aziz, T. (2015). Efficacy of zinc application methods for concentration and estimated bioavailability of zinc in grains of rice grown on a calcareous soil. Pakistan Journal of Agricultural Sciences, 52(1), 169-175.
Ishimaru, Y., Bashir, K., \& Nishizawa, N. K. (2011). Zn uptake and translocation in rice plants. Rice, 4(1), 21-27. https:// doi.org/10.1007/s12284-011-9061-3

Jaksomsak, P., Rerkasem, B., \& Prom-u-thai, C. (2017). Responses of grain zinc and nitrogen concentration to nitrogen fertilizer application in rice varieties with highyielding low-grain zinc and low-yielding high grain zinc concentration. Plant and Soil, 411(1-2), 101-109. https:// doi.org/10.1007/s11104-016-3056-1

Jisha, K. C., Vijayakumari, K., \& Puthur, J. T. (2013). Seed priming for abiotic stress tolerance: An overview. Acta Physiologiae Plantarum, 35(5), 1381-1396. https://doi. org/10.1007/s11738-012-1186-5

Karimi, A., Moezzi, A., Chorom, M., \& Enayatizamir, N. (2019). Chemical fractions and availability of $\mathrm{Zn}$ in a calcareous soil in response to biochar amendments. Journal of Soil Science and Plant Nutrition, 19(4), 851-864. https://doi.org/10.1007/s42729-019-00084-1

Khayyatzadeh, S. S. (2020). Nutrition and infection with COVID-19. Journal of Nutrition and Food Security, 5(2), 93-96.

Ladumor, R. G., Gudadhe, N. N., Onte, S., Narwada, A. V., Nilima, K., \& Thanki, J. D. (2019). Evaluation of maize for different methods and levels of zinc application. Maydica. Available at: https://journals-crea.4science.it/index.php/ maydica/article/view/1983.

Lee, S., Kim, Y. Y., Lee, Y., \& An, G. (2007). Rice $P 1 B$-type heavy-metal ATPase, OsHMA9, is a metal efflux protein. Plant Physiology, 145(3), 831-842. https://doi.org/10. 1104/pp.107.102236

Lee, S., Persson, D. P., Hansen, T. H., Husted, S., Schjoerring, J. K., Kim, Y. S., Jeon, U. S., Kim, Y. K., Kakei, Y., Masuda, H., Nishizawa, N. K., \& An, G. (2011). Bio-available zinc in rice seeds is increased by activation tagging of nicotianamine synthase. Plant Biotechnology Journal, 9(8), 865-873. https://doi.org/10.1111/j.1467-7652.2011. 00606.X

Li, H. J., \& Yang, W. C. (2020). Central cell in flowering plants: Specification, signaling, and evolution. Frontiers in Plant Science, 11, 59030. https://doi.org/10.3389/fpls.2020. 590307

Li, R., Meng, H., Zhao, L., Zhou, H., Shen, Y., Zhang, X., Ding, J., Cheng, H., \& Wang, J. (2019). Study of the morphological changes of copper and zinc during pig manure composting with addition of biochar and a microbial agent. Bioresource Technology, 291, 121752. https://doi.org/10. 1016/j.biortech.2019.121752

Li, X., Wang, H. B., \& Jin, H. L. (2020). Light signaling-dependent regulation of PSII biogenesis and functional maintenance1. Plant Physiology, 183(4), 1855-1868. https://doi.org/10.1104/pp.20.00200

Liu, P. P., Koizuka, N., Martin, R. C., \& Nonogaki, H. (2005). The BME3 (Blue Micropylar End 3) GATA zinc finger transcription factor is a positive regulator of Arabidopsis seed germination. Plant Journal, 44(6), 960-971. https:// doi.org/10.1111/j.1365-313X.2005.02588.x

Long, T. A., Tsukagoshi, H., Busch, W., Lahner, B., Salt, D. E., \& Benfey, P. N. (2010). The bHLH transcription factor POPEYE regulates response to iron deficiency in Arabidopsis roots. The Plant Cell, 22(7), 2219-2236. https:// doi.org/10.1105/tpc.110.074096 
Lu, L., Tian, S., Liao, H., Zhang, J., Yang, X., Labavitch, J. M., \& Chen, W. (2013). Analysis of metal element distributions in rice (Oryza sativa L. ) seeds and relocation during germination based on X-Ray fluorescence imaging of $\mathrm{Zn}$, Fe, K, Ca, and Mn. PLOS One, 8(2), e57360. https://doi. org/10.1371/journal.pone.0057360

Luo, X., Wang, X., Gao, Y., Zhu, J., Liu, S., Gao, G., \& Gao, P. (2020). Molecular mechanism of RNA recognition by zincfinger antiviral protein. Cell Reports, 30, 46-52.

Lutts, S., Benincasa, P., Wojtyla, L., Kubala, S., Pace, R., Lechowska, K., Quinet, M., \& Garnczarska, M. (2016). Seed priming: new comprehensive approaches for an old empirical technique. In S. Araujo (Ed.), New challenges in seed biology-basic and translational research driving seed technology (pp. 1-46). Rijeka: IntechOpen. https://doi.org/ $10.5772 / 64420$

Lv, G. Y., Guo, X. G., Xie, L. P., Xie, C. G., Zhang, X. H., Yang, Y., Xiao, L., Tang, Y. Y., Pan, X. L., Guo, A. G., \& Xu, H. (2017). Molecular characterization, gene evolution, and expression analysis of the fructose-1, 6-bisphosphate aldolase (FBA) gene family in wheat (Triticum aestivum L.). Frontiers in Plant Science, 8, 1030. https://doi.org/10. 3389/fpls.2017.01030

Ma, Z., Bykova, N. V., \& Igamberdiev, A. U. (2017). Cell signaling mechanisms and metabolic regulation of germination and dormancy in barley seeds. Crop Journal, 5(6), 459-477. https://doi.org/10.1016/j.cj.2017.08.007

Mahmoud, A. W. M., Abdelaziz, S. M., El-Mogy, M. M., \& Abdeldaym, E. A. (2019). Effect of foliar $\mathrm{ZnO}$ and $\mathrm{FeO}$ nanoparticles application on growth and nutritional quality of red radish and assessment of their accumulation on human health. Agriculture, 65(1), 16-29. https://doi.org/ 10.2478/agri-2019-0002

Majda, C., Khalid, D., Aziz, A., Rachid, B., Badr, A. S., Lotfi, A., \& Mohamed, B. (2019). Nutri-priming as an efficient means to improve the agronomic performance of molybdenum in common bean (Phaseolus vulgaris L.). Science of the Total Environment, 661, 654-663. https://doi.org/10. 1016/j.scitotenv.2019.01.188

Majumder, S., Datta, K., \& Datta, S. K. (2019). Rice biofortification: High iron, zinc, and vitamin-A to fight against "hidden hunger." Agronomy, 9(12), 803. https://doi.org/ 10.3390/agronomy9120803

McClung, J. P. (2019). Iron, zinc, and physical performance. Biological Trace Element Research, 188(1), 135-139. https://doi.org/10.1007/s12011-018-1479-7

Meagher, J. L., Takata, L., Gonçalves-Carneiro, D., Keane, S. C., Rebendenne, A., Ong, H., Orr, V. K., MacDonald, M. R., Stuckey, J. A., Bieniasz, P. D., \& Smith, J. L. (2019). Structure of the zinc-finger antiviral protein in complex with RNA reveals a mechanism for selective targeting of CG-rich viral sequences. Proceedings of the National Academy of Sciences of the United States of America, 116(48), 24303-24309.

Mirbolook, A., Rasouli-Sadaghiani, M. H., Sepehr, E., Lakzian, A., \& Hakimi, M. (2020). Synthesized Zn(II)-amino acid and -chitosan chelates to increase $\mathrm{Zn}$ uptake by bean (Phaseolus vulgaris) plants. Journal of Plant Growth Regulation. https://doi.org/10.1007/s00344-020-10151-y
Mitra, G. N. (2015). Regulation of nutrient uptake by plants a biochemical and molecular approach. Springer New Delhi Heidelberg New York Dordrecht London.

Mittal, D., Kaur, G., Singh, P., Yadav, K., \& Ali, S. A. (2020). Nanoparticle-based sustainable agriculture and food science: Recent advances and future outlook. Frontiers in Nanotechnology, 2, 579954. https://doi.org/10.3389/fnano. 2020.579954

Moreno-Jiménez, E., Plaza, C., Saiz, H., Manzano, R., Flagmeier, M., \& Maestre, F. T. (2019). Aridity and reduced soil micronutrient availability in global drylands. Nature Sustainability, 2(5), 371-377. https://doi.org/10.1038/ s41893-019-0262-x

Muscogiuri, G., Barrea, L., Savastano, S., \& Colao, A. (2020). Nutritional recommendations for CoVID-19 quarantine. European Journal of Clinical Nutrition, 74, 850-851.

Nadeem, F., \& Farooq, M. (2019). Application of micronutrients in rice-wheat cropping system of south Asia. Rice Science, 26(6), 356-371. https://doi.org/10.1016/j.rsci.2019.02.002

Nadeem, F., Farooq, M., Ullah, A., Rehman, A., Nawaz, A., \& Naveed, M. (2020). Influence of Zn nutrition on the productivity, grain quality and grain biofortification of wheat under conventional and conservation rice-wheat cropping systems. Archives of Agronomy and Soil Science, 66(8), 1042-1057. https://doi.org/10.1080/03650340.2019. 1652273

Naik, S. K., \& Das, D. K. (2007). Effect of split application of zinc on yield of rice (Oryza sativa L.) in an inceptisol. Archives of Agronomy and Soil Science, 53(3), 305-313. https://doi.org/10.1080/03650340701311398

Nciizah, A. D., Rapetsoa, M. C., Wakindiki, I. I., \& Zerizghy, M. G. (2020). Micronutrient seed priming improves maize (Zea mays) early seedling growth in a micronutrient deficient soil. Heliyon, 6(8), e04766. https://doi.org/10.1016/j. heliyon.2020.e04766

Neto, M. E., Britt, D. W., Lara, L. M., Cartwright, A., dos Santos, R. F., Inoue, T. T., \& Batista, M. A. (2020). Initial development of corn seedlings after seed priming with nanoscale synthetic zinc oxide. Agronomy, 10, 307. https:// doi.org/10.3390/agronomy10020307

Noulas, C., Tziouvalekas, M., \& Karyotis, T. (2018). Zinc in soils, water and food crops. Journal of Trace Elements in Medicine and Biology, 49, 252-260. https://doi.org/10. 1016/j.jtemb.2018.02.009

Ogawa, Y., Kinoshita, M., Shimada, S., \& Kawamura, T. (2018). Zinc and skin disorders. Nutrients. https://doi.org/ 10.3390/nu10020199

Ostad-Ali-Askari, K., Shayannejad, M., \& GhorbanizadehKharazi, H. (2017). Artificial neural network for modeling nitrate pollution of groundwater in marginal area of Zayandeh-rood River, Isfahan Iran. KSCE Journal of Civil Engineering, 21(1), 134-140.

Ozturk, L., Yazici, M. A., Yucel, C., Torun, A., Cekic, C., Bagci, A., Ozkan, H., Braun, H. J., Sayers, Z., \& Cakmak, I. (2006). Concentration and localization of zinc during seed development and germination in wheat. Physiologia Plantarum, 128(1), 144-152. https://doi.org/10.1111/j. 1399-3054.2006.00737.x

Pandey, N., Pathak, G. C., \& Sharma, C. P. (2006). Zinc is critically required for pollen function and fertilisation in 
lentil. Journal of Trace Elements in Medicine and Biology, 20(2), 89-96. https://doi.org/10.1016/j.jtemb.2005.09.006

Polishchuk, O. V. (2021). Stress-related changes in the expression and activity of plant carbonic anhydrases. Planta, 253, 58. https://doi.org/10.1007/s00425-02003553-5

Pourmirzaiee, M. A., Chehrazi, S., Heidari-Beni, M., \& Kelishadi, R. (2018). Serum zinc level and eating behaviors in children receiving zinc supplements without physician prescription. Advanced Biomedical Research, 29(7), 120. https://doi.org/10.4103/abr.abr_77_18.PMID: 30211133;PMCID:PMC6124218

Prasad, R., Shivay, Y. S., \& Kumar, D. (2014). Agronomic biofortification of cereal grains with iron and zinc. In D. L. Sparks (Ed.), Advances in Agronomy (vol. 125, pp. 55-91). Academic Press, Elsevier.

Prasad, A. S. (2008). Zinc in human health: Effect of zinc on immune cells. Molecular Medicine, 14(5), 353-357. https://doi.org/10.2119/2008-00033.Prasad

Prom-U-Thai, C., Rerkasem, B., Yazici, A., \& Cakmak, I. (2012). Zinc priming promotes seed germination and seedling vigor of rice. Journal of Plant Nutrition and Soil Science, 175(3), 482-488. https://doi.org/10.1002/jpln. 201100332

Qiao, X., He, Y., Wang, Z., Li, X., Zhang, K., \& Zeng, H. (2014). Effect of foliar spray of zinc on chloroplast $\beta$ carbonic anhydrase expression and enzyme activity in rice (Oryza sativa L.) leaves. Acta Physiologiae Plantarum, 36(2), 263-272. https://doi.org/10.1007/s11738-013-14076

Rahman, M. T., \& Idid, S. Z. (2020). Can Zn be a critical element in COVID-19 treatment? Biological Trace Element Research, 26, 1-9.

Rameshraddy, P. G., Mahesh, S., Geetha, K. N., \& Shankar, A. G. (2017). Seed priming and foliar spray with nano zinc improves stress adaptability and seed zinc content without compromising seed yield in ragi (finger millet). International Journal of Pure and Applied Bioscience, 5(3), 251-258. https://doi.org/10.18782/2320-7051.2906

Rastogi, A., Zivcak, M., Sytar, O., Kalaji, H. M., He, X., Mbarki, S., \& Brestic, M. (2017). Impact of metal and metal oxide nanoparticles on plant: A critical review. Frontiers in Chemistry, 5, 78. https://doi.org/10.3389/fchem.2017. 00078

Read, S. A., Obeid, S., Ahlenstiel, S., \& Ahlenstiel, G. (2019). The role of zinc in antiviral immunity. Advances in Nutrition, 10(4), 696-710.

Rehman, A., Farooq, M., Ozturk, L., Asif, M., \& Siddique, K. H. (2018). Zinc nutrition in wheat-based cropping systems. Plant and Soil, 422(1), 283-315. https://doi.org/10.1007/ s11104-017-3507-3

Rehman, H. U., Aziz, T., Farooq, M., Wakeel, A., \& Rengel, Z. (2012). Zinc nutrition in rice production systems: A review. Plant and Soil, 361(1), 203-226. https://doi.org/10. 1007/s11104-012-1346-9

Rehman, H., Iqbal, H., Basra, S. M. A., Afzal, I., Farooq, M., Wakeel, A., \& Wang, N. (2015). Seed priming improves early seedling vigor, growth and productivity of spring maize. Journal of Integrative Agriculture, 14(9), 1745-1754. https://doi.org/10.1016/S2095$3119(14) 61000-5$
Reis, S., Pavia, I., Carvalho, A., Moutinho-Pereira, J., Correia, C., \& Lima-Brito, J. (2018). Seed priming with iron and zinc in bread wheat: Effects in germination, mitosis and grain yield. Protoplasma, 255(4), 1179-1194. https://doi. org/10.1007/s00709-018-1222-4

Rodríguez-Celma, J., Connorton, J. M., Kruse, I., Green, R. T., Franceschetti, M., Chen, Y. T., Cui, Y., Ling, H. Q., Yeh, K. C., \& Balk, J. (2019). Arabidopsis BRUTUS-LIKE E3 ligases negatively regulate iron uptake by targeting transcription factor FIT for recycling. Proceedings of the National Academy of Sciences of the United States of America, 116(35), 17584-17591. https://doi.org/10.1073/ pnas. 1907971116

Sabir, S., Arshad, M., \& Chaudhari, S. K. (2014). Zinc oxide nanoparticles for revolutionizing agriculture: Synthesis and applications. The Scientific World Journal. https://doi. org/10.1155/2014/925494

Sabir, S., Zahoor, M. A., Waseem, M., Siddique, M. H., Shafique, M., Imran, M., Hayat, S., Malik, I. R., \& Muzammil, S. (2020). Biosynthesis of $\mathrm{ZnO}$ nanoparticles using bacillus subtilis: characterization and nutritive significance for promoting plant growth in Zea mays L. Dose-Response. https://doi.org/10.1177/1559325820958911

Salama, D. M., Osman, S. A., Abd El-Aziz, M. E., Abd Elwahed, M. S. A., \& Shaaban, E. A. (2019). Effect of zinc oxide nanoparticles on the growth, genomic DNA, production and the quality of common dry bean (Phaseolus vulgaris). Biocatalysis and Agricultural Biotechnology, 18, 101083. https://doi.org/10.1016/j.bcab.2019.101083

Saltzman, A., Birol, E., Oparinde, A., Andersson, M. S., AsareMarfo, D., Diressie, M. T., Gonzalez, C., Lividini, K., Moursi, M., \& Zeller, M. (2017). Availability, production, and consumption of crops biofortified by plant breeding: Current evidence and future potential. Annals of the New York Academy of Sciences, 1390(1), 104-114. https://doi. org/10.1111/nyas.13314

Sasaki, H., Hirose, T., Watanabe, Y., \& Ohsugi, R. (1998). Carbonic anhydrase activity and $\mathrm{CO} 2$-transfer resistance in Zn-deficient rice leaves. Plant Physiology, 118, 929-934.

Schuler, M., Rellán-Álvarez, R., Fink-Straube, C., Abadía, J., \& Bauera, P. (2012). Nicotianamine functions in the phloembased transport of iron to sink organs, in pollen development and pollen tube growth in Arabidopsis. The Plant Cell, 24(6), 2380-2400. https://doi.org/10.1105/tpc.112. 099077

Seddigh, M., Khoshgoftarmanesh, A. H., \& Ghasemi, S. (2016). The effectiveness of seed priming with synthetic zincamino acid chelates in comparison with soil-applied ZnSO4 in improving yield and zinc availability of wheat grain. Journal of Plant Nutrition, 39(3), 417-427. https:// doi.org/10.1080/01904167.2015.1069340

Sharma, A., Patni, B., Shankhdhar, D., \& Shankhdhar, S. C. (2013). Zinc — an indispensable micronutrient. Physiology and molecular biology of plants: An International Journal Of Functional Plant Biology, 19(1), 11-20. https://doi.org/ 10.1007/s12298-012-0139-1

Shultz, R. W., Tatineni, V. M., Hanley-Bowdoin, L., \& Thompson, W. F. (2007). Genome-wide analysis of the core DNA replication machinery in the higher plants Arabidopsis and rice. Plant Physiology, 144(4), 1697-1714. https://doi.org/10.1104/pp.107.101105 
Singh, D., \& Prasanna, R. (2020). Potential of microbes in the biofortification of $\mathrm{Zn}$ and $\mathrm{Fe}$ in dietary food grains A Review. Agronomy for Sustainable Development, 40(2), 1-21. https://doi.org/10.1007/s13593-020-00619-2

Skalny, A. V., Rink, L., Ajsuvakova, O. P., Aschner, M., Gritsenko, V. A., Alekseenko, S. I., Svistunov, A. A., Petrakis, D., Spandidos, D. A., Aaseth, J., Tsatsakis, A., \& Tinkov, A. A. (2020). Zinc and respiratory tract infections: Perspectives for COVID-19 (review). International Journal of Molecular Medicine, 46(1), 17-26.

Slamet-Loedin, I. H., Johnson-Beebout, S. E., Impa, S., \& Tsakirpaloglou, N. (2015). Enriching rice with $\mathrm{Zn}$ and $\mathrm{Fe}$ while minimizing Cd risk. Frontiers in Plant Science, 6, 121. https://doi.org/10.3389/fpls.2015.00121

Song, W. Y., Lee, H. S., Jin, S. R., Ko, D., Martinoia, E., Lee, Y., An, G., \& Ahn, S. N. (2015). Rice PCR1 influences grain weight and $\mathrm{Zn}$ accumulation in grains. Plant Cell and Environment, 38(11), 2327-2339. https://doi.org/10.1111/ pce. 12553

Suganya, A., Saravanan, A., Baskar, M., Pandiyarajan, P., \& Kavimani, R. (2020). Agronomic biofortification of maize (Zea mays L.) with zinc by using of graded levels of zinc in combination with zinc solubilizing bacteria and Arbuscular mycorrhizal fungi. Journal of Plant Nutrition. https://doi. org/10.1080/01904167.2020.1845383

Tabesh, M., Kiani, S., \& Khoshgoftarmanesh, A. H. (2020). The effectiveness of seed priming and foliar application of zincamino acid chelates in comparison with zinc sulfate on yield and grain nutritional quality of common bean. Journal of Plant Nutrition, 43(14), 2106-2116. https://doi.org/ 10.1080/01904167.2020.1771579

te Velthuis, A. J. W., van den Worm, S. H. E., Sims, A. C., Baric, R. S., Snijder, E. J., \& van Hemert, M. J. (2010). $\mathrm{Zn}^{2+}$ inhibits coronavirus and arterivirus RNA polymerase activity in vitro and zinc ionophores block the replication of these viruses in cell culture. Plos Pathogens, 6(11), e1001176. https://doi.org/10.1371/journal.ppat.1001176

Tozzi, F., Legua, P., Martínez-Nicolás, J. J., Núñez-Gómez, D., Giordani, E., \& Melgarejo, P. (2020). Morphological and nutraceutical characterization of six pomegranate cultivars of global commercial interest. Scientia Horticulturae, 272, 109557. https://doi.org/10.1016/j.scienta.2020.109557

Tsonev, T., \& Cebola Lidon, F. J. (2012). Zinc in plants-an overview. Emirates Journal of Food \& Agriculture (EJFA), 24(4), 322-333.

Ullah, A., Farooq, M., Rehman, A., Hussain, M., \& Siddique, K. H. M. (2020). Zinc nutrition in chickpea (Cicer arietinum): A review. Crop and Pasture Science, 71(3), 199-218. https://doi.org/10.1071/CP19357

Valença, A. W., Bake, A., Brouwer, I. D., \& Giller, K. E. (2017). Agronomic biofortification of crops to fight hidden hunger in sub-Saharan Africa. Global Food Security, 12, 8-14. https://doi.org/10.1016/j.gfs.2016.12.001

Wang, H. J., Huang, J. C., \& Jauh, G. Y. (2010). Pollen germination and tube growth. Advances in Botanical Research, 54, 1-52. https://doi.org/10.1016/S00652296(10)54001-1
Wani, A. L., Parveen, N., Ansari, M. O., Ahmad, Md. F., Jameel, S., \& Shadab, G. G. H. A. (2017). Zinc: An element of extensive medical importance. Current Medicine Research and Practice, 7(3), 90-98. https://doi.org/10.1016/j.cmrp. 2017.02.006

White, P. J., \& Broadley, M. R. (2009). Biofortification of crops with seven mineral elements often lacking in human dietsiron, zinc, copper, calcium, magnesium, selenium and iodine. New Phytologist, 182(1), 49-84. https://doi.org/10. 1111/j.1469-8137.2008.02738.x

White, P. J., \& Broadley, M. R. (2011). Physiological limits to zinc biofortification of edible crops. Frontiers in Plant Science, 2, 80. https://doi.org/10.3389/fpls.2011.00080

White, P. J., \& Brown, P. H. (2010). Plant nutrition for sustainable development and global health. Annals of Botany, 105(7), 1073-1080. https://doi.org/10.1093/aob/mcq085

Wissuwa, M., Ismail, A. M., \& Graham, R. D. (2008). Rice grain zinc concentrations as affected by genotype, native soilzinc availability, and zinc fertilization. Plant and Soil, 306, 37-48. https://doi.org/10.1007/s11104-007-9368-4

Woodson, J. D. (2019). Chloroplast stress signals: Regulation of cellular degradation and chloroplast turnover. Current Opinion in Plant Biology, 52, 30-37. https://doi.org/10. 1016/j.pbi.2019.06.005

World Health Organization (2002) World Health Report. http:// www.who.int/whr/2002/

Wu, F., \& Wu, C. W. (1987). Zinc in DNA replication and transcription. Annual Review of Nutrition, 7, 251-272. https://doi.org/10.1146/annurev.nu.07.070187.001343

Yruela, I. (2013). Transition Metals in Plant Photosynthesis. Metallomics, 5(9), 1090-1109. https://doi.org/10.1039/ c3mt00086a

Zaman, Q. U., Aslam, Z., Yaseen, M., Ihsan, M. Z., Khaliq, A., Fahad, S., Bashir, S., Ramzani, P. M. A., \& Naeem, M. (2018). Zinc biofortification in rice: leveraging agriculture to moderate hidden hunger in developing countries. Archives of Agronomy and Soil Science, 64(2), 147-161. https://doi.org/10.1080/03650340.2017.1338343

Zhang, W., Zhang, W., Wang, X., Liu, D., Zou, C., \& Chen, X. (2021). Quantitative evaluation of the grain zinc in cereal crops caused by phosphorus fertilization. A Meta-Analysis. https://doi.org/10.1007/s13593-020-00661-0

Zhu, W., Guo, Y., Chen, Y., Wu, D., \& Jiang, L. (2020). Genome-wide identification, phylogenetic and expression pattern analysis of GATA family genes in Brassica napus. Plant Biology, 20, 543. https://doi.org/10.1186/s12870020-02752-2

Zulfiqar, U., Hussain, S., Ishfaq, M., Matloob, A., Ali, N., Ahmad, M., Alyemeni, M. N., \& Ahmad, P. (2020). ZincInduced Effects on productivity, zinc use efficiency, and grain biofortification of bread wheat under different tillage permutations. Agronomy, 10(10), 1566. https://doi.org/10. 3390/agronomy 10101566

Publisher's Note Springer Nature remains neutral with regard to jurisdictional claims in published maps and institutional affiliations. 